\title{
Punkt, linie, flade
}

Refleksioner over fortælling og erfaring

\begin{abstract}
Hvad jeg for min del mener, tilhører mig selv som dette særegne individ; men når sproget imidlertid kun kan udtrykke noget alment, kan jeg ikke sige, hvad jeg for min del mener.
\end{abstract}

Hegel

\section{Om astetisk artikulation}

Når jeg har valgt titlen »punkt, linie, flade« er det ikke for at behandle denne geometriske konstellation som et topos i tænkningens og kunstens historie; det er hverken for at tale om Hegel eller om Kandinsky. Snarere drejer det sig om en association af to forskellige billeder, der falder mig ind i forbindelse med spørgsmålet om fortælling og erfaring.

Det første stammer fra Botho Strauss, hvis seneste bog - Beginnlosigkeit bærer undertitlen $»$ Refleksioner over punkt og linie«. Strauss overvejer her i sin velkendte og mangefacetterede blandingsprosa en række forskellige aspekter af den dissymmetri, der kendetegner forholdet mellem det, som vi oplever, og det, som vi ved om det, vi oplever, - mellem en punktuel intensitet, som kan beskrives på en række forskellige måder, men ikke i nogen omfattende forstand begribes, og en lineær kontinuitet, som kan oversætte dele af - eller momenter i det kaotiske punktuelle nærvær til intelligible kategorier. »Kærlighed er punkt, skrift er linie«, som det hedder. ${ }^{\prime}$

Det, som interesserer Strauss, er den særlige geometri, der kendetegner udvekslingsforholdet mellem det singulære på den ene side - den komplekse, enestående begivenhed -, og den viden herom, som den litterære skrift producerer på den anden. Skriften udsiger det singulære, men til den pris, at det ændrer status, overgår til en anden orden, en anden form. Punktet ophæves i linien, indsættes i en kontekst, der fortolker det og fastholder det, men som samtidig også overdeterminerer det, så det ikke længere lader sig identificere som punkt. Hvad er kærlighed, forstået som en punktuel, singulær oplevelseskvalitet? For at udsige det må skriften trække en linie - man skulle måske sige: én 
tilfældig linie - gennem punktet for at artikulere kvaliteten. Denne artikulation er imidlertid ikke et simpelt, så at sige gennemsigtigt udtryk for kvaliteten, men nødvendigvis også en forvanskning af den, eftersom udsigelsen gør det ulige lige, giver det singulære en almen og forståelig benævnelse. Den strauss'ske punkt-linie geometri insisterer på, at der er en grundlæggende cæsur mellem punktets og liniens ordener: man kan ikke fortælle begivenheden, men man kan lave en fortælling, som på sin side fremstiller sin version af begivenheden og i det samme sætter denne transformerede begivenhed på plads i fortællingens anskuelige eller i hvert fald principielt tilgængelige system. Punktet ophæves ikke i linien på dialektisk og restløs vis; snarere skulle man tale om en slags dissymmetrisk syntese, hvor et bestemt, virtuelt materiale aktualiseres, men hvor man også kunne tænke sig en læng række andre aktualiseringsprincipper, der ville prioritere andre sammenhænge og konstellationer i materialet. Blot eksisterer disse andre sammenhænge og konstellationer ikke for sig: det virtuelle er ikke noget eksisterende: den virtuelle meningssammenhæng må, for at variere en en formulering af Derrida, vente på at blive udsagt for at blive til det, som det til forskel fra sig selv er: en meningssammenhæng. ${ }^{2}$

Den principielle forskel mellem punktet-for-sig og punktet-på-linien - som vel i sig selv kan siges i kortform at resumere nogle væsentlige diskussionsemner indenfor dette århundredes fænomenologi - bidrager til at komplicere svaret på spørgsmålet: hvad er erfaring? Skal erfaringsbegrebet lokaliseres til intensitetens punktuelle orden eller til intelligibilitetens lineære orden? Det passer ikke rigtig nogen af stederne. Den umiddelbare intensitet har oplevelseskarakter, dvs. udg $\emptyset$ r erfaringsstof, men uden at være erfaring, eftersom den er uartikuleret (en slags bevidsthedsmæssig ding-an-sich). Først den intelligible diskurs artikulerer erfaringsstoffet og gør det dermed manifest som erfaring; men omvendt er diskursen ikke selv allerede erfaring, i forhold til erfaringen udgør den alene en transcendental form.

Botho Strauss' interesse for litteraturen som erfaringsorgan skyldes netop, at den litterære skrift kan aktivere punkt-linie geometrien ved at bemorke cæsuren mellem de to ordener. Ved selvbevidst at tage udgangspunkt i ikke-identiteten mellem de to kan litteraturen konstituere sig som en diskursiv praksis, der opfinder måder at tale om vores punktuelle møder med verden omkring os og i os på. Hvis erfaringsbegrebet i den strauss'ske geometri ikke har et entydigt sted i en af de to ordener, er det således fordi det netop hører hjemme i udvekslingen mellem dem. Erfaringsdannelsen, sådan som Strauss interesserer sig for den som et kendetegn ved den litterære diskurs, finder ikke sted på én af de to scener, men i deres mellemrum, idet den enkelte tekst etablerer en ud- 
veksling mellem begivenhed og diskurs, hvor begivenheden er foldet ind i diskursen, og hvor diskursen udfolder en version af begivenheden.

Fortællingen er i denne optik således hverken et medium for en præeksisterende erfaring i gennemsigtig forstand eller en transcendental erfaringsform med bindende gyldighed; fortællingen er en artikulationsform, der kan bemærke et antal singulariteter og aktualisere bestemte træk i dem (nemlig de træk, der er tilgængelige i det perspektiv, fortællingen anlægger). Hermed kommer fortællingens erfaringsaspekt til at ligge i udvekslingen mellem et virtuelt erfaringsstof $i$ en given punktuel intensitet (en begivenhed, en affekt, en indsigt) og den narrative virkeliggørelse - $\mathrm{i}$ betydningen aktualisering af noget virtuelt - af dele heraf. Denne logik er selv mønstergyldigt udfoldet i en af Strauss første romaner, Tilegnelsen. Fortællingens udgangspunkt - det punkt, den kondenserer sig om - er, helt karakteristisk for Strauss' univers, ikke kærligheden, men en kærlighedssorg, at være forladt af den elskede. Romanens hovedperson følger en indskydelse til at bemærke, gennemarbejde og udleve sin væren-forladt; »efter enogtredive år, efter et halvt liv uden biografi i en stille epoke, som ikke skaber skæbner «, som det hedder, ${ }^{3}$ trækker han sig tilbage for at dvæle ved adskillelsen og højtideligholde sorgen, - opgiver vaner, arbejde, dagligdag for at nedskrive sit omvendte kærlighedseventyr, dvs. for dog at transformere den abrupte, men også dagligdags smerte til erfaring. Skriften bliver medium for en proces, der omhyggeligt transformerer det punktuelle je ne sais quoi til biografem.

Denne transformation fra affekt til diskurs implicerer en artikulation af det punktuelle i det lineære og dermed en kontekstualisering af det singulære: det indføjes i en tolkningssammenhæng. Paul Ricœur er nok en af dem, der mest eftertrykkeligt har gjort opmærksom på fortællingens evne til at levere en sådan fortolkningssammenhæng, der kan, som det hedder, konfigurere heterogene punkter i en lineær, temporel struktur. Ricœur jævnfører i værket Temps et récit den aristoteliske narrative struktur med den tidsfænomenologiske erfaringsstruktur, som den unge Heidegger udkaster i Sein und Zeit for at indsætte fortællingen som den ultimative »gardien du temps«, dvs. som den instans, der tillader os at tænke tiden i dens kvalitative, subjektive dimension. Fortællingen kan artikulere en række heterogene punktuelle tildragelser som biografemer, og den kan indordne dem i konstruktionen af en biografi, et forklaret forl $\varnothing \mathrm{b}$ af modning, indsigt, konsekvens, kort sagt - erfaring.

Ricoeurs forestilling om fortællingens konfiguration ${ }^{4}$ af tiden udkaster et magtfuldt og på mange måder uimodsigeligt billede af den ultimative røde tråd, der lader en verden blive til og træde i karakter gennem en fortløbende, kummulativ og hermeneutisk subjektiv erfaringskonstruktion. Jeg skal ikke her opholde mig ved Ricoeurs imponerende og filosofisk højt elaborerede 
konstruktion, blot notere mig den fare, som for mig at se også truer hans projekt, nemlig faren for at ophøje denne fortolkning af den linie, som den enkelte fortælling kan trække, til et ontologisk kendetegn for fortællingen som sådan. Hvis man taler om den klassiske dannelses- og udviklingsroman, kan man i dens narrative univers genfinde en lang række af de træk, som Ricoeur fremhæver i sin bestemmelse af fortællingen. ${ }^{5}$ Men hvis man isolerer en vis historisk prægning af det narrative skema som selve narrativitetens substans, bliver begrebet om fortællingens konfiguration let - som Per Stounbjerg skriver ${ }^{6}$ - til aristoteliske askepotsko, der ikke længere forbinder sig med det, som skulle foranledige fortællingen.

I fortalen til Strauss' roman Den unge mand făr indvendingen mod det typiske, overleverede fortælleskema denne formulering:

»Kom, fortæl os noget, råber fyrene, der hænger udenfor kiosken, når jeg kommer derhen klokken ti om formiddagen for at hente min avis ... Fortælle dem noget? Men de kan jo ikke lytte i bare et minut! Uafladeligt tager de ordet ud af munden på hinanden, og den ene uholdbare påstand vil overgå den anden. Deres samtaler raver af sted, springende og på tværs, fulde af sjuskede klip, som en aften i fjernsynet.«

Konsekvensen heraf formuleres således: Fortælleren må

»drage nytte af det, epoken har opdraget ham i, for eksempel i øvelsen i at få fat på tingene i deres forøgede flygtighed og så for alvor se dem med særlig skarpe konturer. I stedet for at fortælle lige ud ad landevejen vil han tilstræbe en indrammet udvikling, skabe zoner til det diverse, $\mathrm{i}$ stedet for historie vil han gribe det lagdelte øjeblik, den samtidige begivenhed. $\ll^{7}$

Den indsigt, Strauss her berører, er, at den narrative kraft til at fortælle menneskene på et tidspunkt bliver fuldstændig abstrakt og ikke længere strejfer nogle af de punkter, der skulle foranledige fortællingen. Hvis man indskrænker sig til at bestemme linien som et billede på den jernhårde aristoteliske logicitet, mister den sin kraft til at konstruere et aktualiseret erfaringsbillede. For at holde liv i fortællingen som en brugbar måde at etablere et erfaringsunivers på, bliver det nødvendigt at tage afsked med en fortælleform, der ikke længere formår at forholde sig til faktiske tildragelser. Denne sammenhæng understreges allerede i Tilegnelsen på en lidt anden måde, nemlig idet betingelsen for at etablere den biografiske fiktion er, at det skrivende subjekt udsletter det levende subjekt, hvis biografi skulle skrives. Erfaringsdannelsen i det narrative 
univers er ensbetydende med en afsked med det empiriske selv. Fortælleren taler selv om sin skrift som bio-graf: $\gg$ livet, der skriver sig selv efter at have afskediget det skrivende subjekt «. ${ }^{8}$

Ovenfor foreslog jeg at tale om, at fortællingen kan bidrage til at etablere en vis artikulation af det singulære, af det virtuelle erfaringsstof i en punktuel affekt. Men hvis man med nogen ret vil håndhæve den erfaringskonstruerende funktion, der ligger i udvekslingen mellem det singulære og fortællingens orden, er det ikke tilstrækkeligt at artikulere det heterogene i fortællingens konfiguration; omvendt må man også, med et Lyotard-ord, in-artikulere den historisk overleverede fortællende orden, når den kun kan styrte virkeligheden ned $i$ en række præfabrikerede forme, der ikke længere modsvarer en levet virkelighed.

Dette forhold mellem formel artikulation på den ene side og inartikulation af de overleverede former på den anden, leder frem til det andet af de to billeder, jeg indledningsvis nævnte. Det stammer fra Musil og lyder sådan her:

»Det faldt ham [Ulrich, hovedpersonen i Manden uden egenskaber, $\mathrm{ft}$ ] ind, at loven for det liv, som man længtes efter, overbebyrdet som man er og tragtende efter det ukomplicerede, ikke var nogen anden end den fortællende ordens lov! Hin enkle orden, der består i, at man kan sige: 'Da dette var hændt, skete hint!' Det, som beroliger os, er den enkle rækkefølge, afbildningen af livets overvældende mangfoldighed i en ... éndimensionel orden; at trække alt det, som har tildraget sig i tid og rum, på en tråd, netop hin berømte 'fortællingens tråd', som nu også livets tråd består af ... De fleste mennesker er fortællere i det fundamentale forhold til sig selv ... De holder af det ordnede Nacheinander af kendsgerninger, fordi det ligner en nødvendighed, og føler sig ligesom i sikkerhed midt i kaos gennem det indtryk, at deres liv har et ' $\not \varnothing b$ '. Og Ulrich bemærkede nu, at han havde mistet dette primitivt episke, som det private liv endnu holder fast ved, selvom i det offentlige alting allerede er blevet ikke-fortællende og ikke længere fø̆lger en »tråd«, men udbreder sig i en uendeligt sammenvævet flade. $\ll^{9}$

Musils roman kan selv i en lang række henseender betragtes som et bidrag til at in-artikulere de overleverede narrative fremstillingsprincipper, ikke alene for at bringe romanfortællingen i overensstemmelse med en virkelighed, der lader hånt om den fortællende ordens fortolkningsprincipper, men også for at opfinde nye måder til at håndhæve fortællingens evne til at konstruere eksperimentelle erfaringsmønstre. Billedet af tråden, der forsvinder i en uendeligt sammenvævet flade, rummer en præcis karakteristik af Musils strategi for at 
inartikulere den klassiske narrative form: for at komme på sporet af en mulig erfaringskonstruktion skal vi ikke længere gå efter det narrative i romanen, konfigurationen, den røde tråd, "plottet «, ikke efter en lineær betydningsproduktion, men en litterær tekstur, en tekstuel vævning, som afsøger andre måder at tænke det virkelige på, og dermed andre måder at etablere en duelig erfaringskonstruktion på.

Jeg skal ikke anstrenge punkt-linie-flade metaforikken yderligere; det, som jeg med billedet har villet fastholde, er to distinkte litterære logikker, der ofte virker sammen i den moderne litteraturs omgang med de overleverede fortælleformer. Forholdet mellem punkt og linie vedrører således artikulationen af det singulære, der på samme tid fungerer som en italescttelse af det (for nu at bruge Foucaults begreb om »mise en discours «) og samtidig og nødvendigvis en deformation af det, der foranledigede italesættelsen. Forholdet mellem linie og flade rummer i dette perspektiv en slags »anden refleksion« (Adorno) af artikulationens dobbelthed af italesættelse og deformation, idet det kunne stå som overskrift for den nødvendige in-artikulation af de overleverede diskursive former, italesættelsen må betjene sig af, hvilket bliver en strategi for at be-mærke og fastholde det singulære som det, der netop ikke går op i den overleverede diskurs' italesættelsesstrategier. Man kan aldrig udsige det singulære direkte, eftersom dets singularitet netop består i det, som ikke går op i de iterative, diskursive former; ${ }^{10}$ enhver udsigelsesambition vil altid være henvist til en dobbeltstrategi, der omfatter såvel italesættelse som en nødvendig og aktiv deformation af det historiske sprogs former.

I det følgende vil jeg holde mig til Musil for ud fra indledningskapitlet til hans roman at underkaste vekselspillet mellem narrativ artikulation og inartikulation lidt nøjere. Jeg kommer ikke til at følge alle de tekstuelle logikker til dørs, der i denne roman muligvis er på vej til at erstatte den simple narrative ordens traditionelle funktion, hvilket er et langt mere omfattende projekt. Jeg vil alene koncentrere mig om, hvordan Musil konkret, i en enkelt tekstpassage, behandler den overleverede romans fortællemåder, og hvordan han dermed søger at etablere muligheden for at skabe et nyt fiktionsfelt og en ny måde at tildanne den »narrative identitet« på, der ifølge Ricoeur er ankerpunktet for fortællingens kraft til at udkaste modeller for den menneskelige erfaringsdannelse.

\section{Romanbegyndelser}

»Det var en søndag i begyndelsen af april 1813, der allerede fra morgenstunden havde lovet en af de smukke dage, hvor pariserne for første 
gang $\mathrm{i}$ året vågner op til gader uden støv og en himmel uden skyer. Kort før middag kørte en elegant cabriolet med to ilfulde heste ind i rue de Rivoli fra rue Castiglione og standsede bag de andre vogne, der holdt parkeret foran det nyligt åbnede gitter midtfor terrasse des Feuillants. «

Således åbner Balzacs roman La Femme de trente ans ${ }^{11}$ fra 1831. Den smukke forårsdag er ikke bare en smuk forårsdag; det er en pariserforårsdag, et lokalt meteorologisk fænomen, der kan aflæses af det særlige forhold mellem støv i gaderne og skydækket på himlen. Den smukke forårsdag besidder en på samme tid konkret-sanselig og mytologisk kvalitet, ligesom når Balzac i Le Médecin de campagne ikke kan lade være med, til konstateringen »landskabet var smukt«, at føje: »Enfin, c’était la France! « I vognen sidder en ældet herre »hans sparsomme, grånende hår kunne knap dække den gullige isse « - og hans yndefulde datter, der er mødt op for at se Napoleons sidste stolte parade i Paris (»Samtlige tilskuere syntes at ane, hvad fremtiden ville bringe, og nærede måske også en følelse af, at de siden mangen en gang ville komme til at genkalde sig dette sceneri...«).

Miljøet, den første forårsdag, hvor pariserne - de bedre - slår kalechen tilbage, bidrager til at profilere et handlingsmotiv i romanen, adskillelsen mellem den visnende fader og den yppige datter. For et $\varnothing j$ jeblik, hedder det, »udviskedes den sørgmodighed, der stod prentet $\mathrm{i}$ hans ansigtstræk «: han nyder forårspromenaden med den unge pige og soler sig i de passerendes blikke. »De tager dig for min kone, hviskede han til pigen idet han rettede sig op og faldt ind i en langsom gang, der irriterede hende grænseløst.« Han dvæler ved det forår, han står for at miste, mens hun iler mod adskillelsen og den unge officer, som hun straks efter skal møde. Den smukke søndag i april, hvor livet springer ud, er selv et handlingsmotiv; det samme er årstallet, den historiske dato for Napoleons sidste glorværdige parade før de mange svidende nederlag og skuffelser. Den yndige piges blomstrende udfoldelse viser sig nemlig derved selv at skrive sig ind i en faldende kurve, hvor det, som skulle have været vækst og livsbejaelse, dømmes - allerede af tilskuernes bitre forudanelser - til sin uundgåelige skæbne: hybris, svig og nederlag.

De få informationer, som falder på romanens første sider, rummer de væsentligste træk i det, der skal komme: tid og sted rummer allerede in nucleo personernes karakterer, relationer og handlingsmotiver. De tid-rumlige koordinater, som de færreste romanforfattere kan nære sig for at angive indenfor de første ti-femten linier, er hos Balzac andet og mere end et støttepunkt for den læsende fantasi; tiden og rummet bidrager til at bygge et fiktionsrum, der ikke alene er en handlings »scene $\ll$, men hvor scenografien omvendt er isprængt de væsentligste motiver, som handlingsfølgen først skal udfolde. Fik- 
tionsrummet er ikke blot personernes handlingsrum, men indeholder yderligere grundlinierne i den problematik, som deres handlinger udkrystalliserer. »At navngive et sted i en fiktion«, siger Henry James, »er at foregive, at man fremstiller det«. Man må, siger han, lære af Balzac, der »når det drejede sig om Saumur, om Limoges, om Guérande, 'gjorde' Saumur, gjorde Limoges, gjorde Guérande. ${ }^{12}$

Den enhed at miljø, problematik og karakterer, der kendetegner Balzacs romanbegyndelse, er imidlertid selv bundet til forholdsvis snæver epoke i romanens historie. Her er en romanbegyndelse fra 1925 :

»Mrs Dalloway sagde, hun selv ville købe blomsterne.

For Lucy havde allerede nok at bestille. Dørene skulle tages af hængslerne; mændene fra Rumpelmayer skulle komme. Og desuden, hvilken morgen, tænkte Clarissa Dalloway - frisk, som om den var skabt til børn på en strandbred.

Hvilken fryd! At kaste sig ud i den! For sådan havde det altid forekommet hende, når hun med en svag knirken fra hængslerne, som hun nu igen kunne høre for sig, slog de franske døre op og kastede sig ud i den frie luft på Bourton. Hvor frisk, hvor mild, var luften ikke denne tidlige morgen, selvfølgelig mere stille end her: som en bølges slag, en bølges kys; kølig og skarp og dog (for en pige på atten år, som hun var dengang) alvorsfuld, og mens hun stod ved det åbne vindue, følte hun, at noget frygteligt ville ske; hun så på blomsterne, på træerne, som disen snoede sig fri af, og på rågerne, som steg og faldt. Der stod hun og så, indtil Peter Walsh sagde ... $\ll^{13}$

Her er fiktionsrummet kommet i ulave; vi befinder os på flere forskellige steder på samme tid, og der udfoldes flere forskellige tidsplaner ud fra den samme, stedfæstede begivenhed. Verden er opslugt i en bevidsthed, der brudfrit springer mellem steder og tider, en uanselig sanselig detalje er tilstrækkeligt til at vende op og ned på det tid-rumlige univers: duften af morgenluft, lyden af dørenes hængsler (»joints $« !-$ time is out of joint ...). Fiktionsrummets »setting « bliver noget sekundært, eller rettere: det optræder ikke længere som ramme for et forl $\emptyset$; den bevidsthed, der modnes og udfoldes i forløbet, er ikke længere underlagt et fiktivt rum, men danner selv det absolutte udgangspunkt for et mentalt rum.

Godt og vel hundrede år efter Balzacs roman, indleder Sartre sin debutroman Kvalme med disse ord: 
»Det bedste ville være at nedskrive begivenhederne dag for dag. Føre dagbog for ikke at miste blikkets skarphed. Ikke udelade den mindste nuance, de små kendsgerninger, også selvom de kan forekomme betydningsløse. Og fremfor alt bringe orden i dem. Fastholde hvordan jeg ser dette bord, gaden, menneskene, min tobakspung, for det er alt dette, som har forandret sig. Man må bestemme det nøjagtige omfang og den nærmere karakter af denne forandring. ${ }^{14}$

Her er alle ydre bestemmelser borte; tid og sted er uden betydning, og selv fortællerens »jeg « er noget sekundært i forhold til det centrale spørgsmål, hvad det overhovedet vil sige at $s e$ verden. Hos Sartre forvandles romanens diskurs til én lang analyse af de mekanismer, der forbinder - hvis de overhovedet forbinder - individet med verden omkring det. Sartre opgiver det traditionelle konglomerat af miljø, personer og handlinger som et sammenhængende og dynamisk hele; indledningspassagen signalerer, at romanbegyndelsens $t a-$ bleau, som engang kunne udkaste et autoritativt fiktionsrum, har måttet vige for en rakke uvilkårlige spørgsmål, der med udgangspunkt i en simpel konfrontation med den moderne verden skyder alt det, som den klassiske fiktion ubekymret kunne opbygge et univers af, i forgrunden som uoverstigelige problemer.

Denne udvikling fra en klassisk romanbegyndelse, der i få træk udkaster et sammenhængende fiktionsrum, til en moderne, der må begynde ved et nulpunkt, hvis ikke ligefrem før, med den radikale tvivl, er opsummeret og medreflekteret i begyndelseslinierne til Manden uden egenskaber:

$\gg$ Over Atlanterhavet befandt sig et barometrisk lavtryk; det vandrede østpå mod et højtryk liggende over Rusland og røbede endnu ikke tilbøjelighed til at vige nord om dette. Isotermer og isoterer gjorde deres skyldighed. Lufttemperaturen stod i et ordensmæssigt forhold til årets middeltemperatur, til såvel den koldeste som den varmeste måneds temperatur og til den aperiodiske månedlige temperatursvingning. Solens og Månens op- og nedgang, Månens, Venus' og Saturnringens faser og mange andre betydningsfulde fænomener svarede til de derom anførte forudsigelser $\mathrm{i}$ de astronomiske årbøger. Vanddampen i luften havde sin højeste spændkraft, og luftens fugtighed var lav. Med en vending, som ganske godt betegner det faktiske, selv om den er lidt gammeldags: Det var en smuk augustdag i året 1913.«

Med denne åbning forlader Musil ikke allerede den traditionelle romans fiktionsrum; han bibeholder det overleverede indløb til fiktionen, omend det sker 
på en ejendommelig og påfaldende måde. Den første ejendommelighed er, at den »meterologiske « rapport, der giver sig ud for at være en moderne og koncis variant af den omtrentlige formel om den smukke augustdag, slet ikke erstatter sidstnævnte: i stedet for at lade det nye erstatte det forældede, vælger Musil i stedet at stille de to op ved siden af hinanden med en bemærkning om, at den sidste »ganske godt « betegner »det faktiske«. Vi får med andre ord ikke én, men to parallelle og principelt ligeværdige beskrivelser af »det faktiske«. Hermed vægrer Musil sig mod at give et univers med fortællerens overleverede, suveræne gestus; i kraft af gentagelsen denatureres beskrivelsen, der ophører med at være en autoritativ introduktion til fiktionens univers. I stedet erstattes den af to »eksempler på sprog«, to eksperimentelle måder at fremvise et univers på.

Gentagelsen signalerer imidlertid ikke blot, at de to beskrivelser kan være lige gode, men også, at de hver især er lige utilstrækkelige. De to udstiller så at sige hinandens mangler; den sidste viser sig håbløst »gammeldags«, unøjagtig og stemningsmalende, samtidig med at den »eksakte « beskrivelsesmåde viser sig slet ikke at være i stand til at udrede og præcisere alle de betydningsslagger, som den gammeldags indeholder i kraft af sin traditionstilknytning: den giver ikke en ny og bedre beskrivelse, men formår alene at skære alt det approksimative bort. Denne mangel ved den foregivent eksakte diskursart er selv antydet i de ejendommelige, ligesom antropomorfistiske vendinger, der sniger sig ind i den: lavtrykket »røbede ingen tilbøjelighed til ...«, »isotermerne...gjorde deres skyldighed «, de »mange andre betydningsfulde fænomener« svarede til de herom »anførte forudsigelser«. Alle de handlingsmotiver, der i det skjulte klinger med i den »gammeldags « formulering, redes ikke ud og forsynes ikke med et moderne korrelat i den videnskabelige diskurs; i stedet invaderes denne selv af fiktionaliserende elementer, der så at sige slår igennem fra den »gammeldags « måde, som den ikke formår at erstatte. Gentagelsen af »den samme « indledning i to forskellige sprogdragter flytter på denne måde interessen fra de meddelte »kendsgerninger « til meddelelsen selv og til de forskellige måder, man kan lade visse grove iagttagelser danne udgangspunkt for et fiktivt univers, hvad enten dette prioriterer et lavtryks tilbøjeligheder eller andre subjektive agenters impulser.

Hvor Sartre tager konsekvensen af, at repræsentationens traditionelle koder har mistet deres troværdighed $i$ en verden, der modsætter sig forestillingen om et enhedsligt fiktivt univers og dermed forandrer fiktionen til en lang analyse af den uoverstigelige barriere mellem selvet og verden, da vælger Musil, i stedet for alene at medfuldbyrde denne nødvendige konsekvens, at reflektere og indarbejde den i fiktionen selv. Åbningen røber dermed på samme tid en ambition om at bevare et traditionelt fiktionsrum og en bevidsthed om, at dette 
fiktionsrum ikke uden videre lader sig fremstille, men må træde frem i prismatisk belysning gennem en række forskellige diskursarter, der hver prioriterer visse sammenhænge og udelader andre.

Denne dobbelte markering gentager sig i den følgende karakteristik af stedet:

»Biler susede fra smalle, dybe gader ud på lyse, grunde pladser. Fodgængermørke dannede skyagtige snore. Hvor kraftigere streger af hastighed kørte tværs gennem deres løse hastværk, tyknede de, rislede siden hurtigere og havde efter få svingninger deres regelmæssige puls igen. Hundreder af toner var tvundet sammen til en trådet st $\varnothing$, hvoraf enkelte spidser ragede frem, langs hvilken skarpe kanter løb og atter udjævnedes, hvorfra klare toner skilte sig ud og flagrede bort. Skønt støjens særpræg ikke lod sig beskrive, ville et menneske efter årelang fraværelse med lukkede øjne kunne høre på den, at det befandt sig i rigshoved- og residensstaden Wien. Byer kan ligesom mennesker kendes på gangen ... Og skulle det bare være noget, han bildte sig ind, gør det heller ikke noget. Overvurderingen af spørgsmålet om, hvor man befinder sig, stammer fra hordetiden, da man måtte mærke sig foderstederne ... Det afleder fra vigtigere ting.«

Vi kan nu reducere os frem til indledningen $»$ Det var en smuk augustdag $i$ året 1913 ... i rigshoved- og residensstaden Wien«. Det andet led i denne traditionelle indledning brydes efter samme princip som den første; den systemiske og funktionalistiske fremstilling af vektorer, koncentrationer og interferenser rummer ingen af de sanselige eller mytologiske særtræk, der antages at være særlige for Wien. Ikke desto mindre synes denne maskinelle anordning igen »ganske godt « at dække »det faktiske«: maskinens objektive perspektiv modsvarer det subjektive, at vi her befinder os i den gamle rigshoved- og residensstad. Der synes altså trods alt at eksistere en sådan overensstemmelse, der muliggør et samliv mellem den »moderne«, objektive betragtning og den »gammeldags « subjektive perception og dermed endnu en gang redder muligheden for at rejse et traditionelt fiktionsrum på nye betingelser. Dette er imidlertid, får vi at vide, uden betydning: »Det afleder fra vigtigere ting. « De konstrasterende subjektive og objektive beskrivelsesmåder trækkes igen tilbage som tilfældige perspektiver, der går glip af det væsentlige: »Der skal altså ikke lægges særlig vægt på byens navn. Som alle store byer bestod den af uregelmæssighed, skiften, fremadgliden, ikkeholdentrit, sammenstød af ting og anliggender, derimellem bundløse punkter af stilhed, af baner og ubanet, af et stort, rytmisk slag og den evige forstemning og forskydning af alle rytmer mod hi- 
nanden, og lignede alt $\mathrm{i}$ alt en kogende blære, som hviler i et kar af huses, loves, forordningers og historiske overleveringers holdbare stof «. Og passagen fortsætter:

»De to mennesker, der heri gik hen ad en bred, befærdet gade, havde naturligvis slet ikke det indtryk. De tilhørte tydeligt et begunstiget samfundslag, var fornemme i påklædning, i holdning og måden at tale sammen på, bar deres initialer betydningsfuldt broderet på deres linned, og tilsvarende, det vil sige ikke udadvendt, men $\mathrm{i}$ bevidsthedens fine underklædning, vidste de, hvem de var, og at de befandt sig på deres rette plads i en hoved- og residensstad.«

Til de tvetydige tid-rumlige koordinater føjes der nu nogle personer og en social miljø- og karaktertegning, der imidlertid heller ikke får lov at stå uproblematisk frem:

»Hvis man antager, at de hed Arnheim og Ermelinda Tuzzi, hvilket dog ikke er tilfældet, for fru Tuzzi befandt sig i august måned i Bad Aussee ledsaget af sin mand og dr. Arnheim endnu i Konstantinopel, så står man overfor den gåde, hvem de var.«

Den lidt usædvanlige formulering kan læses på to måder: bisætningen kan enten kvalificere den første antagelse ved at negere den, hvormed gåden er, hvem de to personer da kan være (hvis de ikke er fru Tuzzi og dr. Arnheim); eller den kan være et neutralt indskud, hvormed gåden er, hvem netop disse to navngivne personer er, - en gåde, der først delvis bliver løst senere i forløbet, hvor de indtager en ikke ubetydelig rolle i begivenhedernes gang, og netop kun delvis, fordi uklarheden i netop deres identitet og roller i forl øbet selv udgør et handlingsmotiv. Den direkte - og gammeldags - introduktion af to personer med en antydet social baggrund og måde at forholde sig til denne på, relativeres $i$ to henseender: først - i tematisk forlængelse af skildringen af byen som et abstrakt maskineri - idet individernes udskiftelighed og forvekslelighed modsætter sig den uproblematiske bestemmelse af deres identitet; personen er først og fremmest en tilfældig »mand i mængden«, ikke et identificerbart individ. I den moderne storby er også spørgsmålet om, hvem den enkelte person er, »overvurderet«. Havde det imidlertid været tilfældet, at de to personer kunne identificeres som de centrale romanpersoner fru Tuzzi og dr. Arnheim og fiktionsrummet efter gammel skik kunne »zoome fra den overordnede ramme i tid og sted til de centrale og handlingsbærende personer, så havde det stadig været en gåde, »hvem de er«. Den personlige identitet be- 
handles ligesom dagens »skønhed « og den topografiske lokalkolorit: forestillingen om »hvem« nogen »er«, er ikke alene gådefuld i kraft af det moderne, anonyme storbyliv, men yderligere noget principielt ligegyldigt. Romanen kan ikke etablere en meningsfuld åbning ved at navngive visse centrale personer, ligeså lidt som den kan situere en velafgrænset handling i tid og rum.

De tilsyneladende så simple konstateringer »hvornår«, »hvor« og »hvem«, der traditionelt har været faste og uproblematiske koordinater i romanens fiktionsrum, trækkes tilbage fra deres aprioriske umiddelbarhed, ikke nødvendigvis for at blive negeret, men for at blive gjort til genstand for de undrende spørgsmål: »Hvor nu? Hvornår nu? Hvem nu?« - med åbningslinierne fra Becketts Den Unavnelige.

De kendsgerninger, der meddeles i indledningskapitlet under overskriften: »Hvoraf bemærkelsesværdigt intet fremgår«, bidrager ikke til at gestalte et romanunivers; de optræder som en slags tegn i anden potens, der ikke indebærer en kodning, men signalerer en kode. Den ironiske omgang med koderne sætter dem i citationstegn, således at vi ikke alene læser en romanbegyndelse, men samtidig, på ironiens niveau, læser: »dette er en romanbegyndelse«. Hos Musil er romanens sprog igen blevet synligt som (først og fremmest) sprog. Dette betyder imidlertid ikke, at den ironiske gestus selv er fremstillingens slutpunkt; Musils ironi er - med hans egen betegnelse - konstruktiv. Den åbning, der på én gang bekender sin gæld til den traditionelle romans univers og i det samme fremhæver alt det, der forbyder en sådan litterær praksis under indtryk af en forandret verden, tager fiktionens overleverede fordringer på sig og forandrer dem dermed. Af oplysningerne om hvornår, hvor og hvem fremgår intet: den overleverede notering af tid, rum og identitet er kommet til sig selv som en dårlig abstraktion, prædikater for en orienteringsform, der intet væsentligt afslører. Der er imidlertid grund til at hæfte sig lidt nøjere ved dette »intet«. Gentagelsen af den traditionelle romanåbning afslører intet, intet fremgår, intet viser sig. Hvordan viser »intet« sig? Musil insisterer på, at dette skal forstås dobbelt: på den ene side er »intet« privativt: den gammeldags romanbegyndelse kan ikke længere fortætte sig i et fiktionsrum, kan ikke fiksere den ny virkelighed $i$ et anskueligt billede; hvis vi skriver romaner som dengang, får vi intet at vide. Romanbegyndelsen kan ikke artikulere det virkelige. Men på den anden side indbydes vi også til at forstå »intet« som et noget, der viser sig: intet fremgår. I den klassiske romanbegyndelses perspektiv viser intet sig, i privativ forstand, eftersom det, der sker - og indledningskapitlet mangler ikke aktivitet: der sker en masse -, ikke fortætter sig til et romanunivers. I denne forstand viser intet sig som et noget, der blot ikke lader sig fremstille i en allerede eksisterende diskursart, men som bliver synligt i deformeringen af denne overleverede diskurs. 
»Intet« er i denne forstand således ikke simpelt hen at sige ingenting, men intet bestemt; »intet bestemt « er eksistensen af et empirisk »noget «, der kan udlægges og beskrives på forskellige måder; ikke alt muligt, men alt det, som er muligt ud fra den specifikke konstellation. Den »konstruktivt ironiske« omgang med romanens fiktionsrum forandrer det til et virtuelt rum. Det fiktive rum er i almindelighed en måde at udlægge den historiske erfaringsverdens rum på; hos Musil bygges dette rum ikke længere efter den traditionelle romans sæder som en geografisk og tidsmæssigt dateret virkelighed, der vinder sin betydning for det handlende individ, men som et abstrakt mulighedsrum, der tillader en række forskellige fortolkninger af de antydede virkelighedsfragmenters betydning og sammenhæng.

Indledningskapitlet understreger dette forhold $i$ endnu et aspekt; efter »indzoomingen « gennem de faldende grader af abstraktion, fra tid til sted til personer, indføjes en sidste størrelse fra romanens formelle inventarium: en begivenhed. De to personer

»standsede nu pludselig deres skridt, fordi de bemærkede et opløb lidt længere fremme. Et øjeblik forinden var noget sprunget ud af række, en bevægelse slog på tværs; noget havde drejet sig, var skredet sidelæns, en tung, pludseligt bremset lastvogn viste det sig nu, da den stod strandet med det ene hjul på kantstenen ... De tililendes blikke rettede sig mod ... en mand, der lå ligesom død ... Damen følte noget ubehageligt i hjertekulen, som hun var berettiget til at tage for medlidenhed; det var en ubeslutsom, lammende følelse. Efter nogen tavshed sagde herren til hende: »De tunge lastvogne, der bruges her, har for stor bremselængde.« Damen følte sig lettet og takkede med et opmærksomt blik. Hun havde jo nok somme tider hørt dette ord men vidste ikke, hvad en bremselængde var, og ville heller ikke vide det; det var hende tilstrækkeligt, at denne frygtelige begivenhed dermed var at indføje i en eller anden orden og blev til et teknisk problem, som ikke umiddelbart angik hende længere.«

Herrens forklaringer afskaffer begivenheden i en regelmæssighed: intet hændte, bortset fra en på forhånd indkalkuleret lemlæstelse. Det betryggende heri forhindrer dog ikke damen i stadig at have en nu » uberettiget følelse af at have oplevet noget særligt $\ll$. Begivenheden oscillerer mellem disse to, mellem at være en næsten »lovlig og ordensmæssig begivenhed ${ }^{15}$ og noget, der ikke desto mindre efterlader en ubeslutsom, lammende følelse. I det første aspekt er det ikke længere et personligt anliggende, mens den i det andet endnu ikke er blevet det, holdt tilbage i ubeslutsomhedens vage zoner. Den indzooming, der en tid lang focuserer på personerne, formår således ikke at fastholde et person- 
ligt fokus; begivenheden udkrystalliserer ikke et individuelt perspektiv, sætter ikke personerne i spil, men schatteres alene i perspektiver, der ligger »over« og »under « personlighedens rette leje: den samfundsmæssige lovmæssighed og stemningens uanselige tropisme. Den zoomende bevægelse fortsætter derfor så at sige tværs gennem personerne; den stigende grad af konkretion gør ikke holdt ved den énhed, som den personlige identitet endnu i det nittende århundredes kunne udgøre, men fortsætter til den yderste konkretion, billedet af den livløse mand, der ligger på fortovskanten. Den personlige identitet viser sig at være en forgængelig konvention, der ikke længere kan bære den traditionelle romanhandling efter at fremstillingen én gang har stillet skarpt på den; med uhørt konsekvens foretrækker Musil at radikalisere romanens greb og zoome færdig og ende ved det lig, der sætter handlingen i stå. I en vis forstand rummer åbningskapitlets små tre sider en hel roman; den lægger ud in medias res og slutter ved det afsjælede legeme som de allerfleste klassiske romaner, pligtskyldigt gennemskriver den hele det foreskrevne repertoire - tid, sted, personer, begivenheder, færdig - med den ene forskel, at samtlige kategorier er filtrerede gennem den moderne indsigt: tiden bliver et nårsomhelst, stedet et hvorsomhelst, personerne hvemsomhelst og begivenhedernes fatale streng et tilfældigt »man«, der dør sin foreskrevne død.

Romanen begynder med at slutte; »intet « er det hele, alt det, der skal til for at skrive en roman, men som blot ikke længere kan fortætte sig som romanstof, fordi romanens traditionelle formverden ikke længere kan bringe stoffet til kondensation. Dette er baggrunden for, at Musil vælger at vende romanens rum som en handske. Alt det, der ikke længere lader sig gøre, bliver hans rettesnor, hvormed han transformerer den præmature slutning på den »gammeldags « roman til en begyndelse $\mathrm{i}$ hans særlige romanunivers. Romankunstens demiurgiske ambition om at »gøre« virkeligheden $\mathrm{i}$ det symbolske rums koder smuldrer, ikke fordi koderne ikke stadig kan bygge noget, som flertallet ville tage for højst virkeligt - og måske er endda den sidste solide virkelighedsfornemmelse trængt tilbage til sådanne romaner -, men fordi »det faktiske« for et nærmere blik unddrager sig de koder, som det nittende århundredes virkelighedsfornemmelse udtrykte sig igennem.

Efter rask at have åbnet og afsluttet en roman, hvoraf intet fremgår, kan Musil påbegynde den egentlige roman, der nu tager udgangspunkt i den måde, hvorpå ingenting - »bemærkelsesværdigt« - fremgår, nemlig i erkendelsen af, at romanens traditionelle rum forvandler sig til et virtuelt rum, der ikke »gør« en virkelighed, men omvendt kan gennemlyse forskellige aspekter af det mulighedsrum, denne virkelighed er gjort af. På denne måde etableres der en specifik relation mellem det episke i traditionel forstand og det, der netop er karakteristisk ved fraværet af episk kvalitet, idet det episkes smuldrende skema 
bliver fremstillingens målestok; ikke dens kánon - det kan ikke hævdes som absolut - men en bestemt meningsgivende form, der i sin dekompositions proces, som den in-artikuleres konfronteret med den moderne verdens tiltagende abstrakte funktionssammenhænge, sætter stoffet frit. Musils livtag med det moderne er med andre ord ikke en direkte stillen sig ansigt til ansigt med et forvirrende og tilsyneladende meningsfremmed maskineri, der lader hånt om anskuelsens overleverede begreber, men snarere en dobbelt markering af virkelighedsrummet, der først filtrerer det gennem romanfiktionens forældede skemata for derefter at artikulere det netop ved de træk, som det antager idet det unddrager sig denne fixering.

For Musil er »intet« bemærkelsesværdigt, og i en vis forstand handler hans roman om intet, derved at den handler om alt det, der undslipper vores diskursive begribelses netværk. Intethedens analytik, kunne man kalde hans metode. I åbningskapitlet har han samtidig præciseret, at denne analytik ikke stræber direkte mod at udsige det uudsigelige, dvs. det, som er uudsigeligt i en vis, historisk diskursiv orden, men derimod, som Roland Barthes engang har sagt, mod at uudsige det udsigelige. Afslutningsvis vil jeg kort foretage et par spring frem i Musils roman udfra denne problematik og. antyde to mere indholdsmæssige aspekter af intethedens analytik, som kommer på dagsordenen med hans forandring af romanens overleverede form.

Det første aspekt er snarest historiefilosofisk og vedrører karakteren af det intet, der på bemærkelsesværdig måde viser sig i brydningen mellem to forskellige tidsaldres diskursarter, et aspekt, der stiller skarpt på de virtuelle kvaliteter, der kan åbenbare sig i et brud mellem to epoker. Beskrivelsen af » Kakanien« $\mathrm{i}$ kapitel 5 viderefører det futuristiske arrangement fra indledningskapitlet og udmaler billedet af en »super-amerikansk by« som et gennemrationaliseret maskineri af bevægelsesvektorer og stilstandshuller, et »begivenhedernes tog «, hvor »væggene kører ... og kaster deres skinner forud ligesom lange, famlende, krummede tråde, uden at man véd, hvorhen det hele fører. ${ }^{16}$ Rigsog residenshovedstaden Wien anno 1913 er imidlertid ikke, understreges det, allerede denne by, men er alene på vej til at forandre sig til en sådan: »Naturligvis kørte der også automobiler på disse veje, men ikke for mange automobiler! Også her forberedte man luftens erobring, men ikke for intensivt. Hist og her lod man et skib sejle til Sydamerika eller Orienten, men ikke for ofte ... Man udfoldede luksus, men slet ikke så raffineret som franskmændene. Man drev sport, men ikke så naragtigt som angelsakserne. Man gav enorme summer ud til hæren, men dog kun netop så meget, at man var sikker på at være den næstsvageste af stormagterne « osv. ${ }^{17}$ Det rum, handlingen udspiller sig i, kvalificeres således som et rum i forandring mellem to tilstande, - en forandring, der ikke alene borteroderer den traditionelle romanskueplads, men som 
også sætter det fri, som Musils roman orienterer sig efter, nemlig »de uudfyldte rums passive fantasi ${ }^{18}{ }^{18}$

Musil vender i sine dagbøger flere gange tilbage til den unikke situation, som han selv, sammen med sin generation - den »store« generation fra omkring 1880 - befinder sig i: at de har levet i to forskellige verdener, der var radikalt forskellige fra hinanden. De er vokset op, har gjort deres tidlige erfaringer og dannet deres personlighed i »Verden af i går «, mens deres modne år er faldet i det tyvende århundrede, der, som Arnold Hauser har gjort opmærksom på, begyndte i 1914 og allerede var gammelt i 1918. Når de ser tilbage på deres ungdom, betragter de en støvet, fremmedartet verden, der snarere burde være deres bedsteforældres. ${ }^{19}$ Denne diskontinuitetsoplevelse, som ikke alene har at gøre med krigserfaringens monumentalitet, men også med de uhyre politiske, sociale og økonomiske forandringer, krigen afstedkommer, som om et halvt århundrede var koncentreret i disse fire år, har en fremtrædende plads i Musils roman. Når han beskriver den gamle verden i perspektivet »endnu ikke ... men dog allerede« er det således dels for ligesom at fremkalde den modernitet, der i mellemtiden er blevet manifest, hvor den endnu kun eksisterer i kimform, og dels for at få øje på de træk i den gamle verden, der ikke går restløst op i moderniseringen. Den usikkerhed omkring tid og sted, som Musil overalt bestræber sig på at bevare, prioriterer en opmærksomhed overfor det i tidsskildringen, som rummer billedet af en uudfoldet modernitet, og sætter samtidig fokus på spørgsmålet, hvordan denne modernitet eventuelt også kunne være udfoldet på en anden måde. For Musil drejer det sig ikke om at skildre tiden, men om at gentilegne sig tiden som udgangspunkt for noget, der kunne være anderledes. Man genkender heri det benjamin'ske motiv fra de historiefilosofiske teser, ideen om at gentilegne sig det forgangne i lyset af alt det, som det i forgængelighedens perspektiv viser sig at kunne have været.

Det andet aspekt, jeg vil henvise til, der rummer en variation over det »intet «, som in-artikulationen af den overleverede romanform prioriterer, er naturligvis konstruktionen af en hovedperson »uden egenskaber«. Betegnelsen, der efter fire-fem provisoriske titler endte med at give bogen navn, formuleres i romanteksten af Ulrichs barndomsven Walther: »Pludselig brast det ud af ham: 'Han er en mand uden egenskaber!' / 'Hvad betyder det?' spurgte Clarisse ... / 'Intet. Det er netop pointen - det er intet!' «. ${ }^{20} \mathrm{Hvad}$ er et menneske? Dette spørgsmål, som romanen gang på gang og i utallige varianter har forsøgt at besvare gennem fremstillingen af hovedpersonens problematiske sjæl, hans søgen, hans dannelse og hans livsproblem, der skulle sammenfatte, i Sartres formulering, hvad samtiden gør ved mennesket, og hvad mennesket gør ved det, som er gjort ved dette menneske, - dette spørgsmål besvarer Musil med sit rungende $\gg$ intet«. I overensstemmelse med den nyeste positivistiske psyko- 
logi - ikke mindst Ernst Mach, som Musil skrev et filosofisk doktorarbejde om - afskaffer Musil den idealistiske forestilling om et enhedsstiftende selv: »Jeget er ikke en monade, isoleret fra verden omkring det, men en del af verden, midt i den selv samme flod ... Et isoleret jeg er ligeså utænkeligt som en isoleret ting. Tingen og jeget er provisoriske fiktioner af samme art. $\ll^{21}$ Musil overtager og radikaliserer denne kritiske skepsis overfor den humanistiske fiktion - med Ulrichs ord: »Det er ikke længere et helt menneske, der står overfor en hel verden, men et menneskeligt Noget, der bevæger sig i en almindelig næringsvæske ${ }^{22}$

Musils udgangspunkt er, at menneskelivet i det moderne bliver tiltagende abstrakt; ${ }^{23}$ samtidig sondrer han imidlertid mellem en dårlig abstraktion, nemlig det afmægtige fors $\emptyset \mathrm{g}$ på at »være nogen « midt i det uendelig formidlede, og så den villet abstrakte tilværelse, der tager menneskelivets ændrede vilkår op som en udfordring efter devisen: »Man må lære at bemægtige sig sit transcendentale jeg. $\ll^{24}$ Ulrichs aggressive afkald på den personlige eksistens' staffage er et eksperiment, hvis indsats er muligheden for at subjektivere en impuls, der ikke på forhånd er skrevet ind i den gamle fiktion om »den hele person«. Dermed făr indsigten i den ubønhørlige borterosion af det gamle humanistiske subjekt tillige en etisk dimension, som udgør den anden side af Musils kulturkritik: bestandig at overveje, hvordan det »intet«, som er, hvad der blev tilbage af det humanistiske subjekt, kan tænkes og bringes til fremstilling.

»En mand uden egenskaber består af egenskaber uden mand «, hedder det forklarende i en kapiteloverskrift; »intet« er ikke en ikkeværen, men et antal værens-fragmenter uden samlende form. Sønderbrydningen af den klassiske subjektive form efterlader ikke et simpelt tomrum, men et artikuleret fravær, en eksistens af en række forskellige (og måske uforenelige) erfarings- og handlingssubjekter $i$ samme individ. Gennembrydningen af identitetens skin er i denne forstand en betingelse for i fiktionen at kunne skildre og analysere de virkende kræfter og motiver i erfaringsdannelsens og den mellemmenneskelige interaktions processer.

Musils minimalontologi går til angreb mod den transcendentale narcissisme, ikke for patetisk at hævde intetheden og tomheden som eksistensens grund, men for med udgangspunkt i det, han kalder »den historiske dementi af det antropocentriske forhold «, at kunne udkaste nye litterære modeller for, hvori en menneskelig erfaringsdannelse kunne bestå. Ved at inartikulere romanens traditionelle form gør han sig på denne måde samtidig til arvtager til dens historiske projekt, idet han hermed kommer frem til at stille sig dannelsesromanens gamle spørgsmål: hvordan det er muligt at konstruere et erfaringsunivers, der ikke på forhånd er determineret af en overleveret forestilling om subjektets og erfaringens form. 
1. Botho Strauss: Beginnlosigkeit. Reflexionen über Fleck und Linie, München 1992.

2. Jf. formuleringen: »Meningen må vente på at blive sagt eller skrevet for at bebo sig selv og blive til det, som den til forskel fra sig selv er: meningen«. L'écriture et la différence, Paris 1967, p.72.

3. Botho Strauss: Tilegnelsen, København 1980), p.15.

4. Se Temps et récit, bd. 1, Paris 1983, p.116ff.

5. De samme træk, i parantes bemærket, som Ernst Bloch hæfter sig ved, når han karakteriserer Hegels fænomenologi som en mønstergyldig dannelsesroman, - blot for at understrege, at fiktionen ikke bør betragtes som en illustration af et bestemt erfaringsparadigme, men at det emfatiske, dialektiske erfaringsbegreb selv netop i første hånd må begribes som en fikton, en fortælling; jf. Ernst Bloch: Subjekt-Objekt. Erläuterungen zu Hegel, Frankfurt am M. 1961, p.75ff.

6. »Omkring den selvbiografiske fortælling «, foredrag ved seminaret 'Fortællingen i litteratur og videnskab', AUC, december 1992, se artiklen i dette nr. af $K \& K$.

7. Botho Strauss, Den unge mand, København 1985, p.10, 12.

8. Op.cit., p.24.

9. Robert Musil: Der Mann ohne Eigenschaften, ed. Adolf Frisé, Hamburg 1972, p.651.

10. Til relationen mellem singulært og iterativt, se Derridas $\gg$ Signature, evenement, contexte« in: Marges - de la philosophie, Paris 1972, spec. p.382ff., samt interviewet med Derrida i Derek Attridge (ed.): Acts of literature, New York 1982, spec. p.68ff.

11. Dk. ovs. Kvinden paa 30 Aar.

12. »Forord til Roderick Hudson«, Den Blå Port, 15-16, København 1990.

13. Virginia Woolf: Mrs Dalloway, København 1984 (Ovs. mod.).

14. Jean-Paul Sartre: »La nausée«, in: Oeuvres romanesques, Paris 1981, p.5.

15. Op.cit.

16. Til dette rænonnement, se også Antoine Compagnon: Proust entre deux siècles, Paris 1989.

17. Op.cit., p.36.

18. Op.cit., p.37.

19. Op.cit., p.39.

20. Ernst Mach: Erkenntnis und Irrtum. Skizze zur Psychologie der forschung, Leipzig 1906, citeret efter Manfred Frank: »Auf der Suche nach einem Grund. Über den Umschlag von Erkenntniskritik in Mythologie bei Musil«, in: K.-H. Bohrer (Hrsg.): Hythos und Moderne, Frankfurt am M. 1983, p.325.

21. Op.cit., p.71.

22. » 'På landet kommer guderne endnu til menneskene,' tænkte U., 'man er noget og oplever noget, men i byen, hvor der er tusind gange så mange oplevelser, er man ikke længere i stand til at bringe dem i relation til én selv, og sådan begynder vel den berygtede tilstand, at livet bliver mere og mere abstrakt' «, p.649.

23. Op.cit., p.238.

24. Ordene er Hölderlins, citeret af Musil i Tagebücher, Bd. 1, Adolf Frisé (Hrsg.), Hamburg 1976, p.363. 
